\title{
Plantar foot vibration thresholds: a comparison between measurements with seated and standing subjects
}

\author{
AMC Germano*, G Schlee, TL Milani \\ From 3rd Congress of the International Foot and Ankle Biomechanics Community \\ Sydney, Australia. 11-13 April 2012
}

\section{Background}

The importance of the somatosensory information from the plantar foot area for balance control is well reported in the literature. Usually, tests for touch and vibration sensitivity are performed with subjects in sitting or supine position [1]. However, balance tests are measured in standing position [2]. Therefore the aim of this study was to compare vibration thresholds measured with subjects seated and during standing.

\section{Materials and methods}

Sixty-six healthy subjects of both genders with a mean age of $22.1( \pm 3.2)$ years participated in this study. Vibration perception thresholds $[\mu \mathrm{m}]$ were measured at $200 \mathrm{~Hz}$ in two conditions: sitting (90 ${ }^{\circ}$ knee angle) and standing on both legs. Five measurements with increasing amplitude were performed at each of the three analyzed anatomical locations of the right plantar foot: heel, first metatarsal head (MET I) and hallux. The contact force between the vibration probe and the anatomical locations as well as foot temperature were controlled throughout the experiments. Body position and anatomical locations were randomized between the subjects.

\section{Results}

The contact forces between the probe and the location were higher for standing in comparison to sitting condition (27, 7\% hallux, 43, 2\% Met I and 62, 6\% Heel). However, no significant differences in vibration thresholds between standing and sitting conditions were found in any of the analysed anatomical locations (Figure 1).

\footnotetext{
* Correspondence: andresa.germano@s2010.tu-chemnitz.de Department of Human Locomotion, Chemnitz University of Technology, Chemnitz, Germany

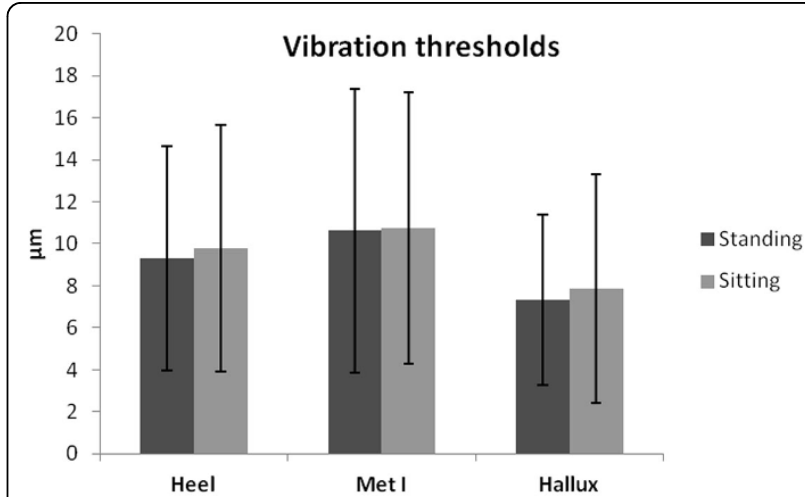

Figure 1 Vibration thresholds for the standing and sitting conditions.

\section{Conclusions}

Cassella et al. (2000) demonstrated that greater contact forces between the probe and the location being analysed are reducing vibration thresholds. However, despite the higher force applied by the probe during standing, no significant differences between the tested positions were evaluated in the present study. It seems that the standing position affects the perception of vibration stimuli, since subjects need to concentrate on different tasks, e.g. keep their balance. This could explain the lack of differences between thresholds measured in the different positions, although contact forces increased during standing.

Published: 10 April 2012

\section{References}

1. Dietz V: Human neuronal control of automatic functional movements: interaction between central programs and afferent input. Physiol Rev 1992, 72:33-69. 
2. Chiang $\mathrm{JH}, \mathrm{Wu} \mathrm{G}$ : The influence of foam surfaces on biomechanical variables contributing to postural control. Gait Posture 1997, 5:239-245

3. Cassella JP, Ashford RL, Kavanagh-Sharp V: The effect of applied pressure in the determination of vibration sensitivity using the neurothesiometer. The Foot 2000, 10:27-30.

doi:10.1186/1757-1146-5-S1-023

Cite this article as: Germano et al.: Plantar foot vibration thresholds: a

comparison between measurements with seated and standing subjects. Journal of Foot and Ankle Research 2012 5(Suppl 1):O23.

Submit your next manuscript to BioMed Central and take full advantage of:

- Convenient online submission

- Thorough peer review

- No space constraints or color figure charges

- Immediate publication on acceptance

- Inclusion in PubMed, CAS, Scopus and Google Scholar

- Research which is freely available for redistribution

Submit your manuscript at www.biomedcentral.com/submit
C Biomed Central 